\title{
Akciğer kanserinde nadir görülen yaygın cilt metastazı
}

\author{
Nargiz MAJIDOVA ${ }^{1}$ \\ Güzin DEMiRAĞ ${ }^{2}$ \\ Mehtap PEHLIVANLAR \\ KÜÇÜK ${ }^{3}$
}

${ }^{1}$ Ondokuz Mayıs Üniversitesi Tıp Fakültesi, i̇ç Hastalıkları Anabilim Dalı, Samsun, Türkiye

${ }^{1}$ Department of Internal Medicine, Faculty of Medicine, Ondokuz Mayis University, Samsun, Turkey

2 Ondokuz Mayıs Üniversitesi Tıp Fakültesi, Onkoloji Bilim Dalı, Samsun, Türkiye

2 Division of Oncology, Faculty of Medicine, Ondokuz Mayis University, Samsun, Turkey

${ }^{3}$ Ondokuz Mayıs Üniversitesi Tıp Fakültesi, Göğüs Hastalıkları Anabilim Dalı, Yoğun Bakım Bilim Dalı, Samsun, Türkiye

${ }^{3}$ Division of Intensive Care, Department of Chest Diseases, Faculty of Medicine, Ondokuz Mayis University, Samsun, Turkey

\section{ÖZET}

Akciğer kanserinde nadir görülen yaygın cilt metastazı

Elli yedi yaşında erkek hasta öksürük ve balgam şikayetleri olması nedeniyle kliniğimize başvurdu. Bilgisayarlı tomografide sol 7. kosta lateralinde $36 \times 25 \mathrm{~mm}$ kitle, sağ ana bronşu oblitere eden $50 \times 52 \mathrm{~mm}$ kitle ve paratrakeal, karinal büyüyü $40 \times 34 \mathrm{~mm}$ lenf nodları ve sağ sürrenalde $60 \times 42 \mathrm{~mm}$ boyutunda ve kemikte yaygın metastaz saptandı. Yapılan bronkoskopik biyopsiyle skuamöz hücreli karsinom tanısı konuldu. Ciltde yaygın lezyonlar saptanması üzerine kafa derisi biyopsisi alındı. Cilt biyopsisi skuamöz hücreli karsinom infiltrasyonu olarak raporlandı. En son ayak tabanındaki metastaza radyoterapi verilirken hipotansiyon ve ateş olması üzerine yoğun bakım ünitemize kabul edildi. Bu çalışmada, akciğer kanserinin bir tipi olan skuamöz hücreli kanserde agresiv seyirli, yaygın cilt metastazının nadir görülmesi nedeniyle güncel literatür verileri ışığında tartısılması amaçlanmıştır.

Anahtar kelimeler: Akciğer kanseri; cilt metastazı; prognoz

\section{ABSTRACT}

\section{Aggressive skin metastasis in lung cancer}

A fifty seven year old male patient was admitted to our clinic because of complaints of cough and sputum. Computed tomography revealed by a $36 \times 25 \mathrm{~mm}$ mass on the lateral of the $7^{\text {th }}$ left rib, a $50 \times 52 \mathrm{~mm}$ mass on the right main bronchus, growing $40 \times 34 \mathrm{~mm}$ lymph nodes on the carina and paratracheal, $60 \times 42 \mathrm{~mm}$ mass on the right adrenal and extensive bone metastasis. Squamous cell carcinoma was diagnosed by performed bronchoscopic biopsy. Scalp dermal biopsy was taken upon detection of extensive lesions on the skin. Scalp biopsy was reported squamous cell carcinoma infiltration. The last time when was given radiotherapy to footwell metastasis, the patient was fever and hypotension, we were accepted intensive care unit. In this article, we aimed to discuss rarely aggressive skin metastasis in a squamous cell carcinoma, a type of lung cancerin the light of current literature data.

\section{Yazışma Adresi (Address for Correspondence)}

Dr. Nargız MAJIDOVA

Ondokuz Mayıs Üniversitesi Tıp Fakültesi, İç Hastalıkları

Anabilim Dalı, SAMSUN - TÜRKIYE

e-mail: nergiz.mecidova1991@gmail.com 


\section{GíRiş}

Her yıl dünyada yaklaşık 1 milyon kişi akciğer kanserinden ölmektedir. Akciğer kanseri, özellikle skuamöz hücreli kanseri cilt metastazı yapması nadirdir, \%1-12 oranında görülmektedir. Akciğer kanseri erkeklerde cilt metastazına neden olan kanserler arasında ilk sıradayken, kadınlarda meme kanserinden sonra ikinci sıradadır (1). Akciğer kanseri cilt metastazı erkeklerde daha sık görülür, genellikle yaşamın 6. ya da 7. dekatlarında ortaya çıkar.

Histopatolojikolarak, ciltmetastazı değerlendirildiğinde epidermisden ilişkisiz dermisde yer yer veya yaygın tümör hücrelerinin görülmesi ve tümör hücre infiltrasyonunun lenfatik drenajın şeklini alması veya lenfatik drenajı doldurmasıyla tanı konulmaktadır. Bu bulgular primer cilt tümörü değil, metastaz olmasını kuvvetle desteklemektetir.

Biz de skuamöz hücreli akciğer kanseri cilt metastazı olgusunu yaygın ve dramatik cilt lezyonları olması nedeniyle sunmaya uygun bulduk.

\section{OLGU SUNUMU}

Elli yedi yaşında erkek hasta nefes darlığı, öksürük, balgam, ara ara ateş olması nedeniyle kliniğimize başvurdu. Öyküsünden bu yakınmaların 5 aydır varolduğu ve giderek arttı̆̆ı öğrenildi. Özgeçmişinde 3 yıldır kronik obstrüktif hastalığı $(\mathrm{KOAH}), 1.5$ yıldır dilate kardiyomiyopati, 1 yıldır konjestif kalp yetmezliği ve 30 paket/yılı sigara kullanım öyküsü mevcuttur. Fizik muayenesinde genel durumu iyi, TA: 120/80 mmHg, nabız: $96 / \mathrm{dk}$, ritmik, dolgun, ateş: $36.4^{\circ} \mathrm{C}^{\prime} \mathrm{ydi}$. Başvurudaki fizik muayenede her iki akciğer bazallerde solunum sesleri azalması dışında normaldi. Laboratuvar bulgularl; albumin: $2.25 \mathrm{~g} / \mathrm{dL}$ ve hemoglobin: $7.8 \mathrm{~g} / \mathrm{dL}$ olması dışında normaldi. Bilgisayarlı tomografide (BT)'de sol 7. kosta lateralinde $36 \times 25 \mathrm{~mm}$ kitle, sağ ana bronşu oblitere eden $50 \times 52 \mathrm{~mm}$ kitle ve

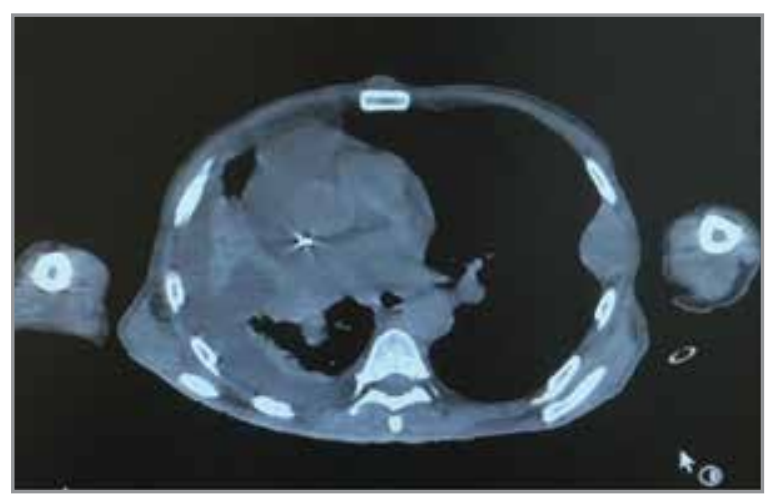

Resim 1. Olgunun toraks bilgisayarlı tomografi (BT) kesiti. paratrakeal, karinal büyüğü 40 × 34 mm lenf nodları ve sağ sürrenalde $60 \times 42 \mathrm{~mm}$ boyutunda ve kemikte yaygın metastaz saptanmıştır (Resim 1). Akciğer sağ üst lob ve orta lob girişi mukozayı infiltre eden kitleden bronkoskopik biyopsi alındı. Patolojisi skuamöz hücreli karsinom olan hastanın takibinde ciltte yaygın kitleler saptandı. Pozitron emisyon tomografisinde sağ akciğerde kitle, sağ sürrenal, iskelet sisteminde yaygın metastaz, sağ burun kanadı, ayak tabanı ve saçlı deride kronik ülser saptandı. Kafa derisindeki ülserden alınan cilt biyopsisi patolojisi skuamöz hücreli karsinom infiltrasyonu olarak değerlendirildi. Biyopsi materyalinin histopatolojik incelemesinde epidermisten ilişkisiz dermisde yer yer mitotik fibroz içeren solid adalar ve dermal kollajen içerisinde infiltre tümör hücreleri ve aynı zamanda dermiste intralenfatik tümör trombüsleri izlendi (Resim 2-4). Kafa derisi cilt metastazlarına radyoterapi uygulandı. Sonrasında gemsitabin, karboplatin, zoledronik asit tedavileri verilmiştir. Takiplerinde sol sternoklaidomastoid bölgede progresif nodül olması üzerine dosetaksel ve zoledronik asit tedavisine geçilmiştir. En son ayak

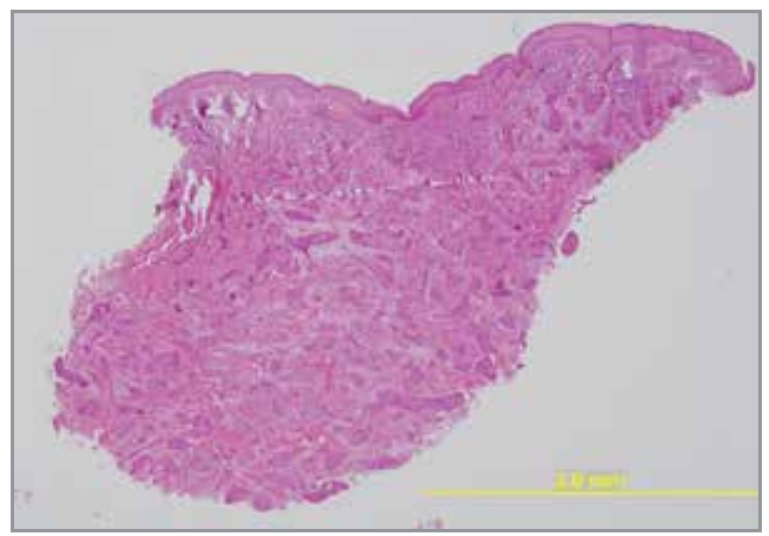

Resim 2. Olgunun cilt biyopsisi histopatolojik incelemesi x40, HE.

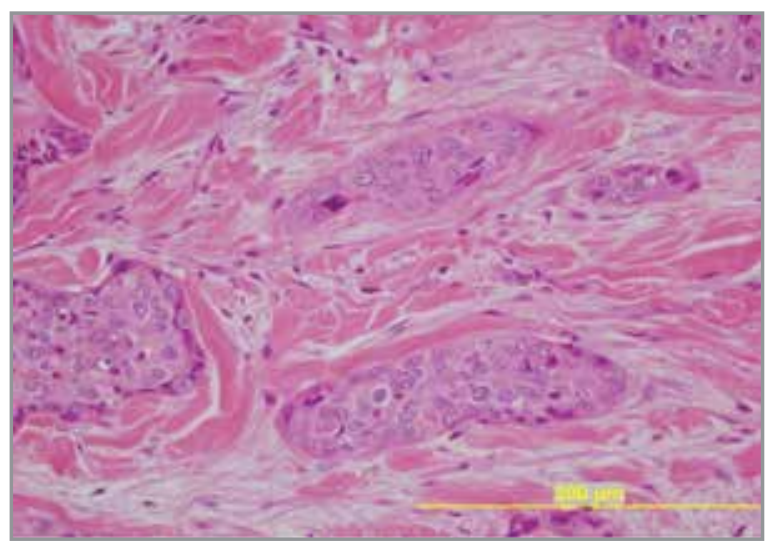

Resim 3. Olgunun cilt biyopsisi histopatolojik incelemesi x40, HE. 


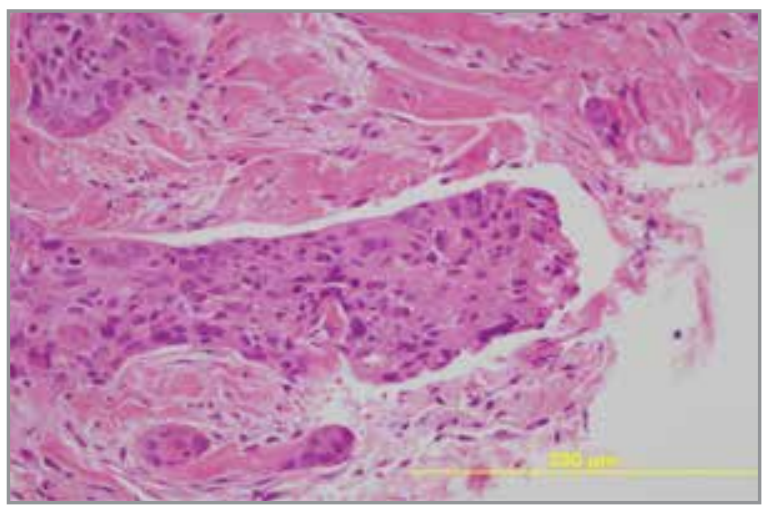

Resim 4. Olgunun cilt biyopsisi histopatolojik incelemesi x40, HE.

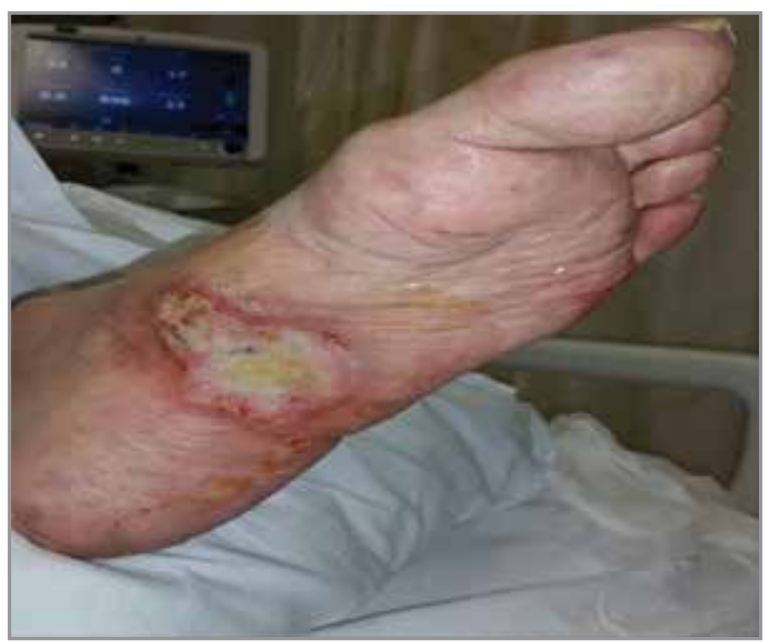

Resim 5. Olgunun ayak tabanındaki ülseri.

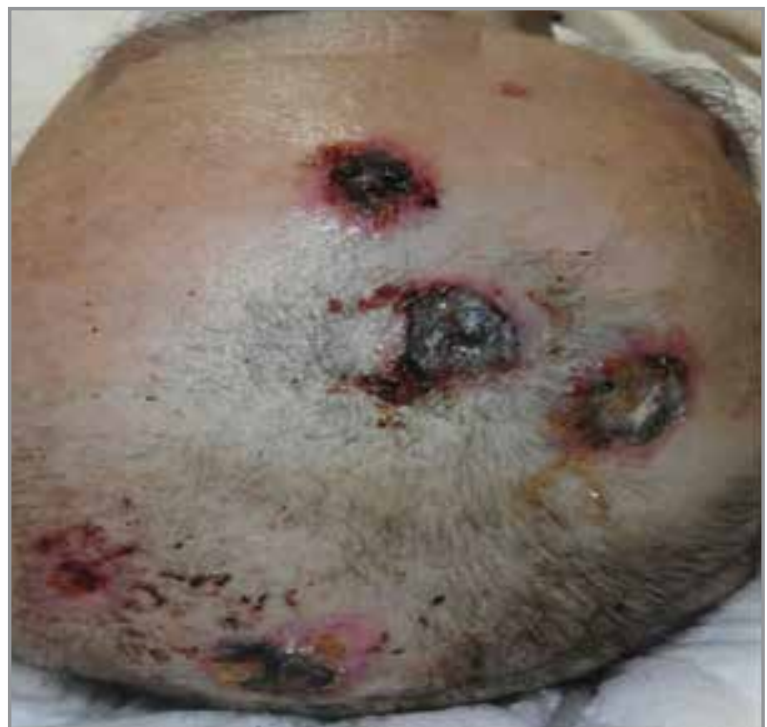

Resim 6. Olgunun yoğun bakımdaki baş boyun muayenesi.

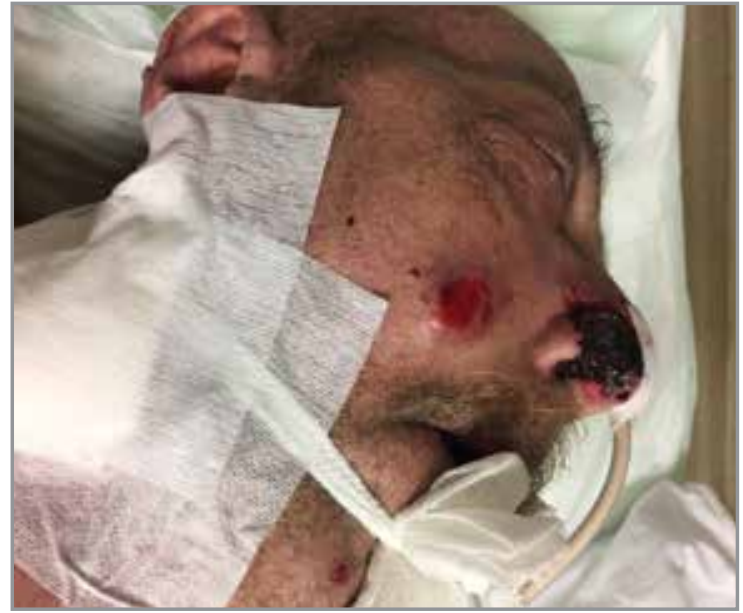

Resim 7. Olgunun yoğun bakımdaki baş boyun muayenesi. tabanına radyoterapi alırken genel durum bozukluğu,

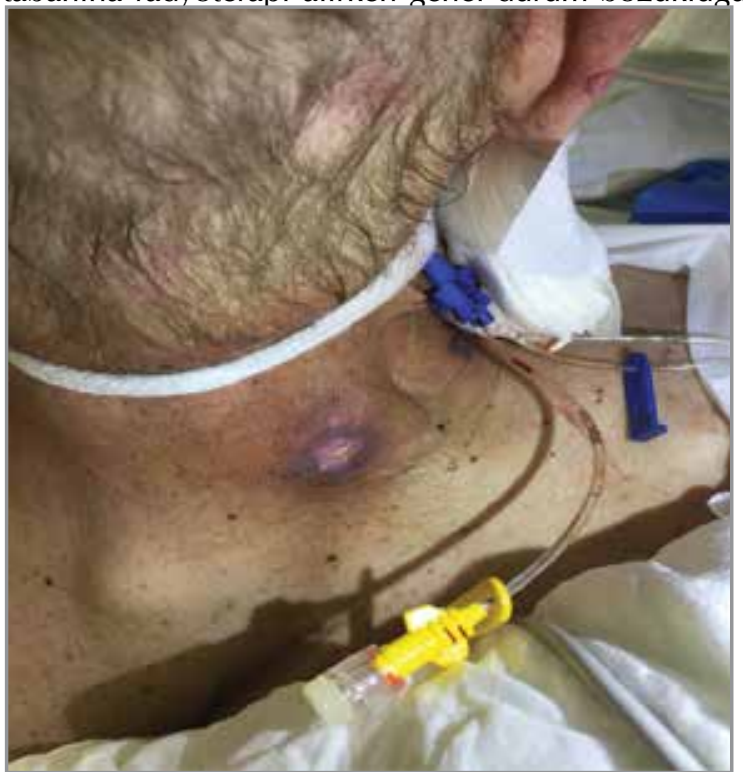

Resim 8. Olgunun yoğun bakımdaki baş boyun muayenesi.

ateş ve hipotansiyon olması üzerine yoğun bakım ünitemize kabul edildi (Resim 5). Yoğun bakım ünitesindeki fizik muayenesinde kafa cildinde çevresi ekimotik ve nekroze görünümde ortası ülsere infekte birkaç adet 2-3 cm'lik lezyonlar, ensede 1 adet ülsere $1.5 \mathrm{~cm}^{\prime}$ lik lezyon, sağ burun kanadını kaplayan yüzeyden hafif kabarık nekroze lezyon ve sağ yüz üst molar diş hizasında tabanı hemorajik yaklaşık 1.5 cm'lik lezyon, batın cildinde 3-4 adet nodüler lezyonlar ve ksifoid üzerine lokalize hemorajik tabanlı yaklaşık $1.5 \mathrm{~cm}$ 'lik ülsere lezyon saptandı (Resim 6-9). Hasta mekanik ventilatör desteğinde ve çoklu inotropla takipliyken tanı anından 3 ay sonra kaybedildi. 


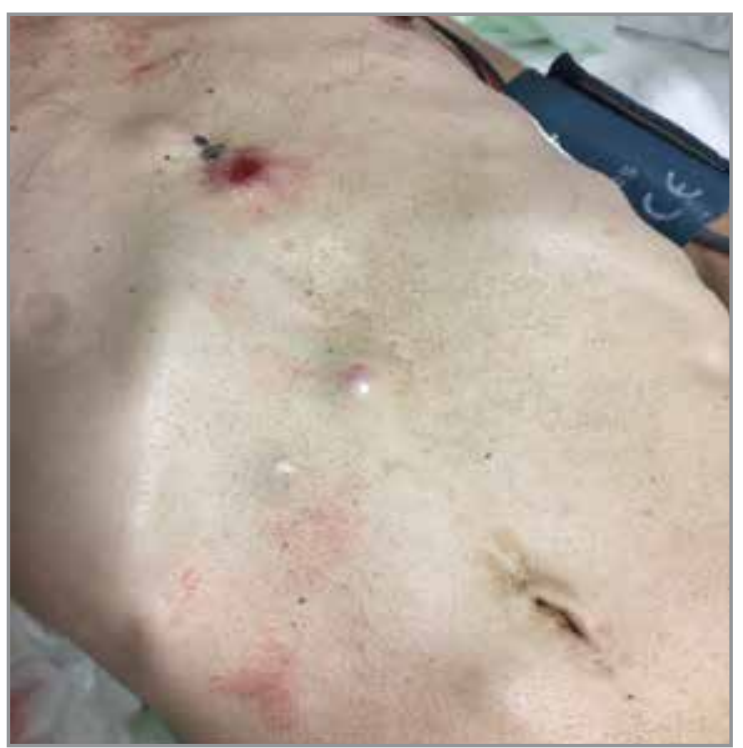

Resim 9. Olgunun yoğun bakımdaki batın muayenesi.

\section{TARTIŞMA}

Akciğer skuamöz hücreli kanser (SCC)'inde, cilt metastazı gelişimi nadirdir ve son yıllarda akciğer iç organ kanserleri içinde cilde en sık metastaz yapan organdır. Cilt metastazı sıklığı yaşla birlikte artar ve 6 . dakikadan sonra daha sık görülür $(1,2)$. Hastamızda da olduğu üzere ortalama görülme yaşı 57.5-65 arasındadır ve cilt metastazı tanısından sonra ortalama sağkalım süresi 3 ila 5 ay arasında değişir. Genellikle var olan kanserin seyri sırasında ortaya çıkar. Cilt metastazları o zamana kadar bilinmeyen bir kanserin ilk belirtisi olabileceği gibi, tam olmayan remisyonların ilk relaps bulgusu da olabilir. Cilt lezyonları, kanserli olgunun hem tanısal aşamasında, hem de izleminde araştırılmalı ve varlığında göz ardı edilmemesi gereken bir bulgudur $(3,4)$.

\section{SONUÇ}

Akciğer kanserinde cilt metastazı olan hastaların prognozu kötüdür. Uzun süre sigara kullanan, malignite şüpheli, orta ve ileri yaşlı erkeklerde, yeni beliren tüm cilt lezyonlarından biyopsi alınarak histopatolojik inceleme yapılması gerektiği kanaatindeyiz.

\section{KAYNAKLAR}

1. Ambrogi V, Nofroni I, Tonini G, Mineo TC. Skin metastases in lung cancer: analysis of a 10-years experience. Oncol Rep 2001;8:57-61.

2. Ediboğlu Ö, Arı G, Tuksavul F, et al. Akciğer kanserli olgularımızda cilt metastazı. İzmir Gögüs Hastanesi Dergisi 2003;2:65-8.

3. Leffell DJ, Carucci JA. Management of skin cancer. In: De Vita VT, Hellman S, Rosenberg SA, eds. Cancer: Principles and Practice of Oncology $6^{\text {th }}$ ed. Philadelphia: Lippincott Williams\&Wilkins 2001.

4. Schoenlaub P, Sarraux A, Grosshans E, Heid E, Cribier B. Survival after cutaneous metastasis: a study of 200 cases. Ann Dermatol Venereol 2001;128:1310-5. 